\title{
PROPRIEDADES MECÂNICAS E MICROESTRUTURA DE TUBOS DE AISD SAF 2507 COM 8 MM DE ESPESSURA SOLDADOS POR ATRITO COM PINO NÃO CONSUMÍVEL*
}

\author{
Rafael Arthur Reghine Giorjão ${ }^{1}$ \\ Victor Ferrinho Pereira ${ }^{2}$ \\ Maysa Terada ${ }^{3}$ \\ Eduardo Bertoni da Fonseca ${ }^{4}$ \\ Ricardo Reppold Marinho ${ }^{5}$ \\ Diego Martins Garcia ${ }^{6}$ \\ André Paulo Tschiptschin ${ }^{7}$
}

\begin{abstract}
Resumo
Microestrutura e propriedades mecânicas de tubos de aço inoxidável superduplex SAF 2507 processados por soldagem por atrito com pino não consumível foram analisadas. Juntas de alta qualidade foram produzidas com sucesso utilizando ferramentas de nitreto de boro cúbico policristalino (PCBN), controle de força de $38 \mathrm{kN}$, velocidade de avanço de $50 \mathrm{~mm} / \mathrm{min}$, velocidade de rotação de $200 \mathrm{RPM}$. Ensaios de dureza e tração foram realizados, evidenciando aumento de dureza na zona de mistura e falha no metal de base. Simulações térmicas calcularam temperaturas globais máximas em torno de $1176{ }^{\circ} \mathrm{C}$ e diferentes ciclos térmicos ao longo da espessura da junta, conferindo diferenças microestruturais e mecânicas nestas regiões

Palavras-chave: Soldagem por atrito com pino não consumível; Aço inoxidável superduplex; simulação térmica.

\section{MICROSTRUCTURE AND MECHANICAL PROPERTIES OF FRICTION STIR WELDED 8 MM PIPE SAF 2507 SDSS}

\section{Abstract}

The microstructure and mechanical properties of 8-mm-thick friction stir (FS) welded SAF 2507 superduplex stainless steel pipe were examined. High-quality welds were successfully produced using polycrystalline cubic boron nitride (PCBN) tool, force control mode of $38 \mathrm{kN}$, travel speed of $50 \mathrm{~mm} / \mathrm{min}$, rotational speed of $200 \mathrm{RPM}$. Hardness and tensile tests were performed, showing hardness increase in the stir zone and failure on the base metal. Thermal simulation showed maximum global temperatures around $1176{ }^{\circ} \mathrm{C}$, and different thermal cycles along the joint thickness, providing microstructural and mechanical differences along the welded joint.

Keywords: Friction stir welding; 2507 SDSS; thermal simulation.

1 PhD student in friction stir welding - Materials. Metallurgical Engineer. National Nanotechnology Laboratory

2 Master student in friction stir welding - Materials. Mechanical Engineer. National Nanotechnology Laboratory

$3 \quad P h D$ In Nuclear Technology - Materials. Researcher. National Nanotechnology Laboratory (CNPEM)University of Campinas School of Mechanical Engineering, LNNano/CNPEM, Campinas, São Paulo-Brazil

4 Master friction stir welding - Materials. Mechanical Engineer. National Nanotechnology Laboratory Polytechnic

$5 \quad P h D$ In Stainless Steels - Materials. Engineer. Petrobras

6 Master in Welding. Welding Consultant. Petrobras. Rio de Janeiro, Brazil.

$7 \quad \mathrm{PhD}$ In Phase Transformation - Materials. Lecturer. University of São Paulo. 


\section{INTRODUCTION}

Super duplex stainless steel (SDSS) are biphasic ferrite-austenite alloys based on the $\mathrm{Fe}-\mathrm{Cr}-\mathrm{Ni}$ system (1). The two-phase structure of ferrite and austenite combines the beneficial effects of the phases and allows a global high strength (ferrite) and toughness (austenite) even at low temperatures $(1,2)$. SDSS exhibit higher resistance to stress corrosion cracking and strength than austenitic stainless steels, widely used in many applications as structural materials in various industrial sectors including chemical, petrochemical, power generation, pulp and paper, and pollution control industries (1).

SDSS family alloys have good weldability, however, special care is required to assure mechanical properties are unchanged after the process. The interference on properties depends on the welding process used. In the case of arc welding, there is a direct influence of the welding energy, the process employed (energy density effect) and the deposition technique. These parameters affect the phase balance in SDSS resulting in poor mechanical properties and corrosion resistance (1).

In the case of friction stir welding (FSW), a solid-state process, there is an important influence of the thermal and mechanical history to which the material is subjected and very little is known under the effect of each one of these factors in the microstructure and final performance of the joint (3).

Recent investigations showed that FSW can produce defect-free welds, on SAF 2507 (4) and SAF 2205 (5,6). In these studies, FSW refined the two constituent phases in the stir zone (SZ), and hence mean hardness and tensile strength were improved in the weld zone. Sato et al. found that FSW in 2507 SDSS significantly refined the ferrite and austenite phases through dynamic recrystallization.

Despite the advance in solid-state joining of SDSS, the development of thicker joints in pipeline welding has also been an important factor in welding technology. Recent studies have reported significant cost savings when using FSW to join thicker material sections (7). While FSW typically travels slower than traditional arc welding processes, it is capable of joining thicker sections in a single pass resulting in significant cost savings when building large steel structures such as oil and gas pipelines, offshore platforms, or heavy machinery and maintaining its mechanical and corrosion resistance to values equal or superior to the base metal. Recent studies have produced plate joints in $1.5 \mathrm{~mm} \mathrm{(8),} 2 \mathrm{~mm}(5), 4 \mathrm{~mm}(4)$ and $6 \mathrm{~mm}$ (9) duplex stainless steels with excellent surface finish and complete penetration. The literature does not report any FSW study in thicker plates nor thicker pipes.

The present work characterizes mechanically and microstructurally 8-mm-thick SDSS SAF 2507 circumferential joints produced by friction stir welding. Hardness and tensile tests were performed to verify the mechanical resistance of the joint and further microstructural characterization was used to understand the effect of the process thermal cycles in the material.

\section{MATERIALS AND METHODS}

Two SDSS SAF 2507 130-mm-long pipes were machined. The internal and external diameter were respectively $168.3 \mathrm{~mm}$ and $184.3 \mathrm{~mm}$, conferring a total of 8 $\mathrm{mm}$ in thickness. A schematic view of the pipe geometry is illustrated in Figure 1-(a). No additional bevel preparation was used before the joining procedure. 
The tool was a 7.72-mm-long step-spiral conical pin with a plane threaded shoulder made of metallic matrix composite PCBN-WRe (25\%Re-W alloy reinforced with $60 \%$ vol Polycrystalline Cubic Boron Nitride), illustrated in Figure 1-(b).

(a)

\section{Tool position}

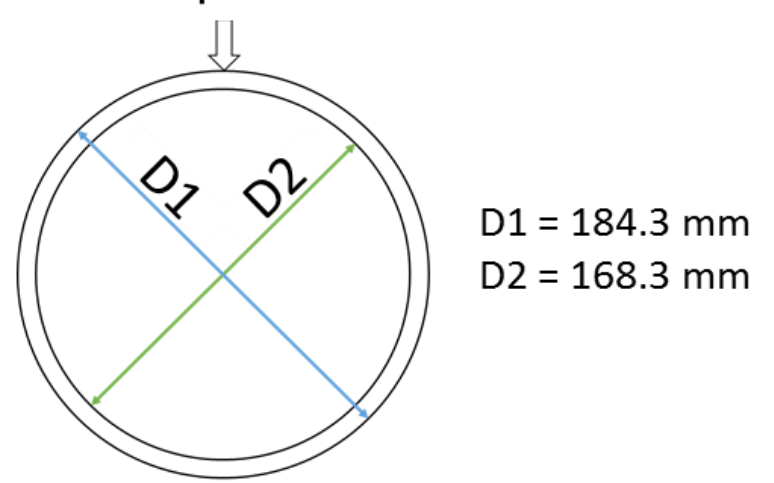

(b)

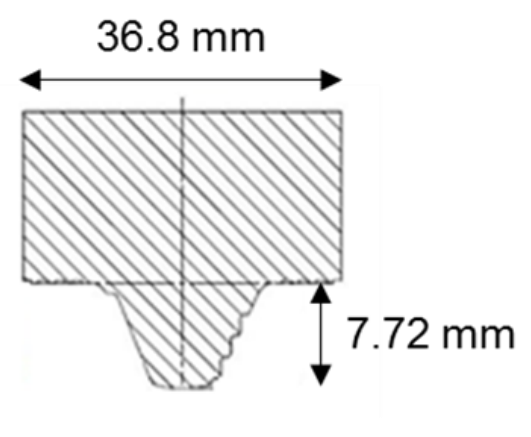

Figure 1: (a) Pipe dimensions and welding direction schematics. (b) Tool geometry dimensions

A force control mode was made with a total tool penetration of $38 \mathrm{kN}$ in the axial direction with a travel speed of $50 \mathrm{~mm} / \mathrm{min}$, spindle speed of $200 \mathrm{RPM}$. These parameters were selected based on a previous work in 2205 plates $(6,9)$ and in-house development. During welding, axial force, torque and tool temperature were obtained and analyzed. Microstructure was examined by optical microscopy (OM) and scanning electron microscopy (SEM). Samples for OM and SEM examination were electrolytically etched in a $40 \%$ nitric acid solution. Vickers hardness test was conducted on the cross-section perpendicular to the welding direction, using a Vickers indenter with a $200 \mathrm{~N}$ load for $15 \mathrm{~s}$, to examine the hardness distribution. Transverse tensile specimens were removed perpendicular to the welding direction. Tensile tests were carried out at room temperature on a $250 \mathrm{kN}$ MTS tensile testing machine at a crosshead speed of $3 \mathrm{~mm} / \mathrm{min}$.

Thermal simulation was performed in three-dimensional finite element (FE) model developed using commercial software COMSOL v5.2. Assuming steady-state conditions, the model calculated the thermal cycles during the process. Welding parameters for the simulations were constant, such as axial force $(38 \mathrm{kN})$, spindle speed (200 RPM) and welding speed (50 mm/min). Tetragonal elements with smaller sizes (ranging from 2 to $20 \mathrm{~mm}$ ) in the regions near the tool than the rest of the workpiece were used at the mesh.

Free convection boundary conditions were applied to the workpiece surfaces. Thermal radiation boundary condition was also applied to the top surface of the workpiece with an emissivity coefficient. Heat transfer through the backing plate and tool top were considered and convection boundary conditions were applied to the side and to the top of the tool. All coefficients are listed in Table 1 were based on previous work and in-house development (6). Due to the complexity associated with modeling the friction stir welding tool with a step-spiral pin, a conical shape with a smooth pin surface (without threads) was used.

Table 1: Heat transfer coefficients applied to the thermal model 


\begin{tabular}{cc}
\hline Condition & Coefficient \\
\hline Free convection & $20 \mathrm{~W} / \mathrm{m}^{2} \mathrm{~K}$ \\
Surface radiation & 0.3 \\
Side tool convection & $20 \mathrm{~W} / \mathrm{m}^{2} \mathrm{~K}$ \\
Top tool convection & $500 \mathrm{~W} / \mathrm{m}^{2} \mathrm{~K}$ \\
Backing plate & $2000 \mathrm{~W} / \mathrm{m}^{2} \mathrm{~K}$ \\
\hline
\end{tabular}

The heat source considers two conditions: a surface heat generation and a volume heat source, based on Schmidt and Hattel work (10). The volume flux is calculated from the average power input $\mathbf{P}_{\text {avg }}$ during welding expressed by Eq (1), where $\mathbf{M}_{\mathbf{a v g}}$ is the average torque measured during welding and $\omega$ is the tool rotation speed.

$$
P_{\text {avg }}=M_{\text {avg }} \omega
$$

Using equation (2), the volume flux can be calculated analytically using Eq (2)

$$
Q_{\text {volume }}=\frac{f_{\text {pin }} P_{\text {avg }}}{V_{\text {pin }}}
$$

where $\boldsymbol{V}_{\boldsymbol{p} \text { in }}$ is the tool pin volume and $\boldsymbol{f}_{\boldsymbol{p} \text { in }}$ is the percentage of heat generation from the pin side relative to the total heat generation. For this work, a value of $20 \%$ for $\boldsymbol{f}_{\text {pin }}$ was used based on the work of Colegrove et al (2000).(11).

The surface heat flux expression must account for the heat generated by friction and by plastic deformation, expressed by equation (3)

$$
Q_{\text {surface }}=\left(1-f_{\text {pin }}\right)\left[\delta_{\tau_{\text {yield }}(T)}+(1-\delta) \tau_{\text {friction }}\right] \omega r
$$

where $r$ is the radial distance from the tool center, $\boldsymbol{\tau}_{\text {friction }}$ is the frictional stress at the tool/workpiece interface, $\boldsymbol{\delta}_{\boldsymbol{\tau}_{\text {yield }}(\mathbf{T})}$ is the material yield shear stress at the welding temperature $\mathbf{T}$ at this same interface and $\boldsymbol{\delta}$ is a contact state variable that balances the heat generated by friction and by plastic deformation.

To account for the non-symmetric heat generation in the welding process, equation (5) can be rewritten as Eq. (4)

$$
\mathrm{Q}_{\text {surface }}=\left(1-\mathrm{f}_{\text {pin }}\right)\left(\omega r-U_{\text {weld }} \sin \theta\right) \tau_{\text {yield }}(\mathrm{T})
$$

The model coefficients were calibrated using an inserted thermocouple into the tool head and attached to the FSW machine. This thermocouple positioned by the tool shoulder does not provide the exact tool temperature at the interface with the processing material within the SZ. However, due to the high thermal conductivity of PCBN, it provides a comparative value for various welding parameters (12).

\section{RESULTS AND DISCUSSION}

The appearance of the weld surface is shown in Figure 1. It is observed good surface conditions, with little flash and no superficial defects. 


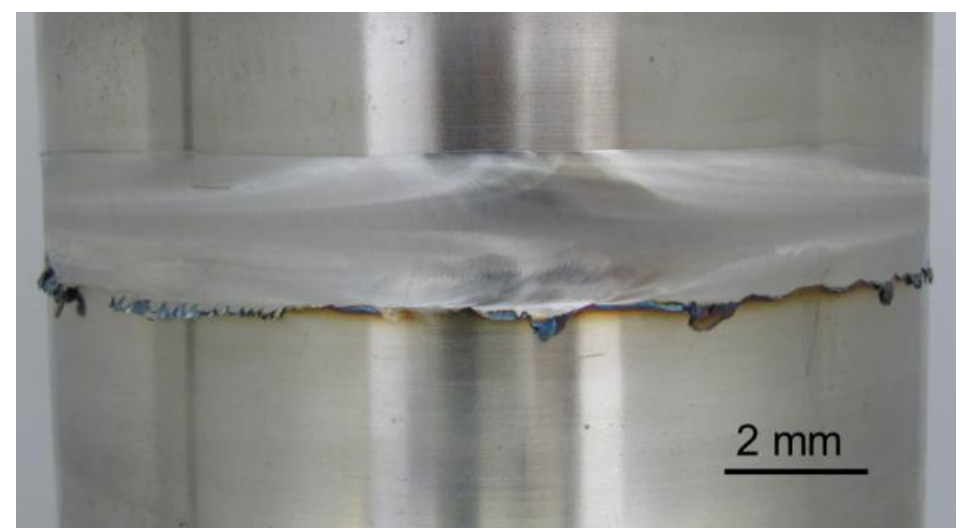

Figure 1: Superficial conditions of the SAF 2507 welded pipe.

The results of force, torque and temperature are seen in Figure 2. Both axial force and torque presented variation throughout the process, with values varying between 37.5 and $38 \mathrm{kN}$ for axial force and 225 and $260 \mathrm{~N} . \mathrm{m}$ for torque. These variations suggest geometrical irregularities presented in the workpiece, resulting in variation of the tool response throughout the process. Both axial force and torque values are dependent on both size and geometry of the tool and the material to which it interacts, so they are often not reported in publications. However, for comparison purposes, Saied welding $2 \mathrm{~mm}$ duplex plates 2205 with a $3.8 \mathrm{~mm}$ tool obtained maximum values of axial force of $14 \mathrm{kN}$. The smaller values are due the less material displacement promoted by the $3.8 \mathrm{~mm}$ tool compared to $7.8 \mathrm{~mm}$ tool used in this paper. Temperature measured reached max values of $805^{\circ} \mathrm{C}$ in $160^{\circ}$ position. The values of temperature changed according to the torque and axial response of the machine, rising after torque pikes and axial down pikes.

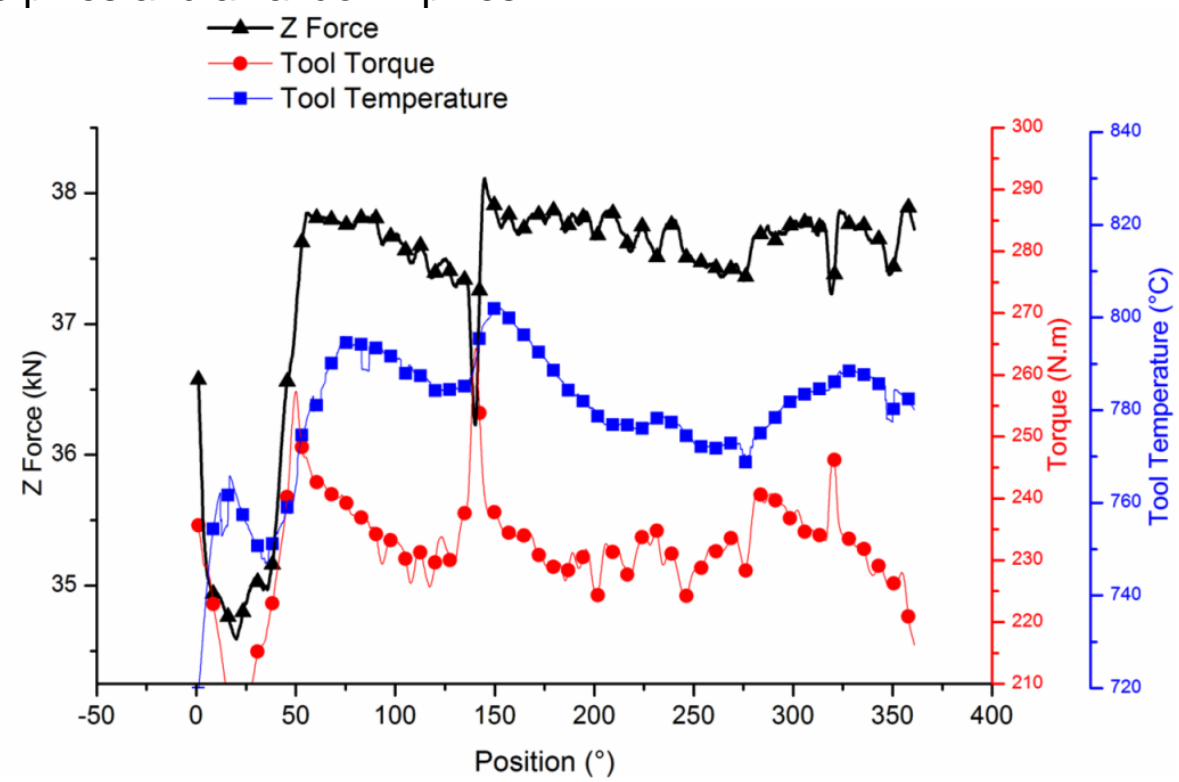

Figure 2: Axial $(Z)$ force, torque and tool temperature along the welding process.

\section{Hardness and tensile test results}

Figure 3 shows the cross-section of the weld bead at low magnification, indicating the advancing side and retreating side of the joint. It is apparent that a sound joint was produced. It is also noted an incomplete root joint, possibly due to lack of penetration of the tool during welding. 


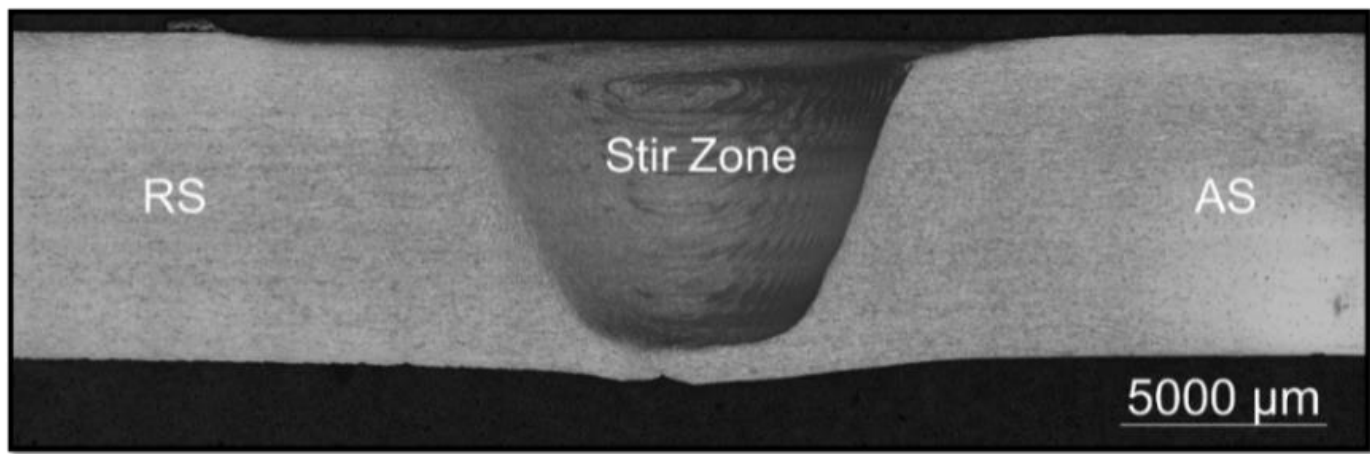

Figure 3: Cross-section of the joint, highlighting the stir zone in central region, advancing and retreating sides of the joint.

The transverse hardness profile of the FSWed SAF 2507 super duplex stainless steel is indicated in Figure 4. Maximum values reached $400 \mathrm{HV}$ in the advancing side/root region. The overall stir zone reached values around $325 \mathrm{HV}$, slightly higher on the advancing side. Esmailzadeh et al. (2013) processing lean duplex stainless steels reached hardness values around $350 \mathrm{HV}$ for 800 RPM rotational speed and 150 $\mathrm{mm} / \mathrm{min}$ transverse speed (8). The author relates the hardness increase to the smaller grain sizes found in the stir zone.

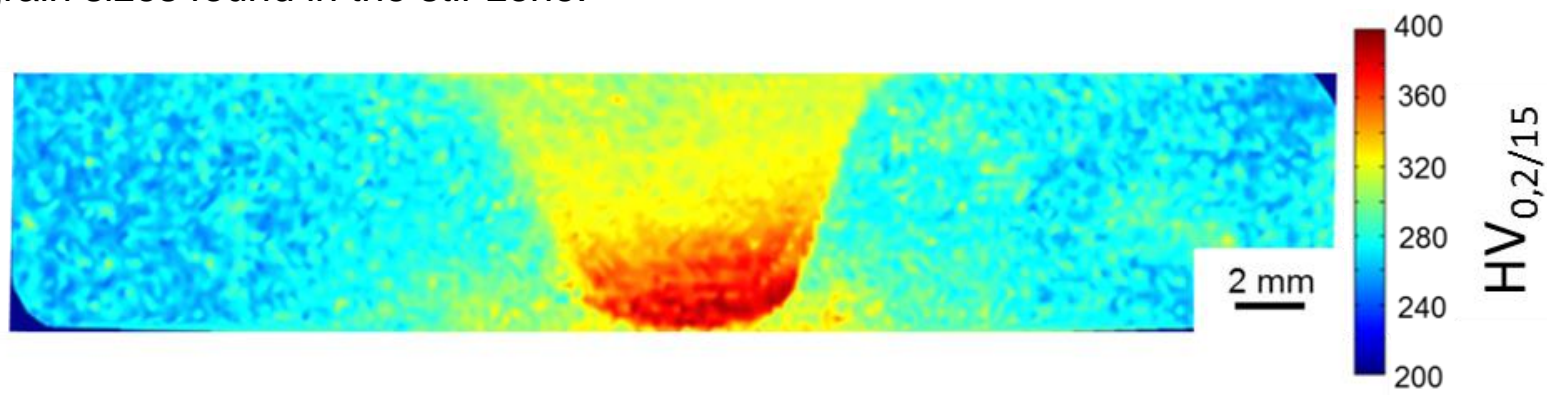

Figure 4: Hardness map of the FSWed SAF 2507 SDSS.

Tensile test specimens failed roughly $40 \mathrm{~mm}$ from the weld center, located in the base metal, as seen in Figure 5. Comparing to the hardness results, the failure occurred on lower hardness sites, which is proportional to strength of metallic materials.

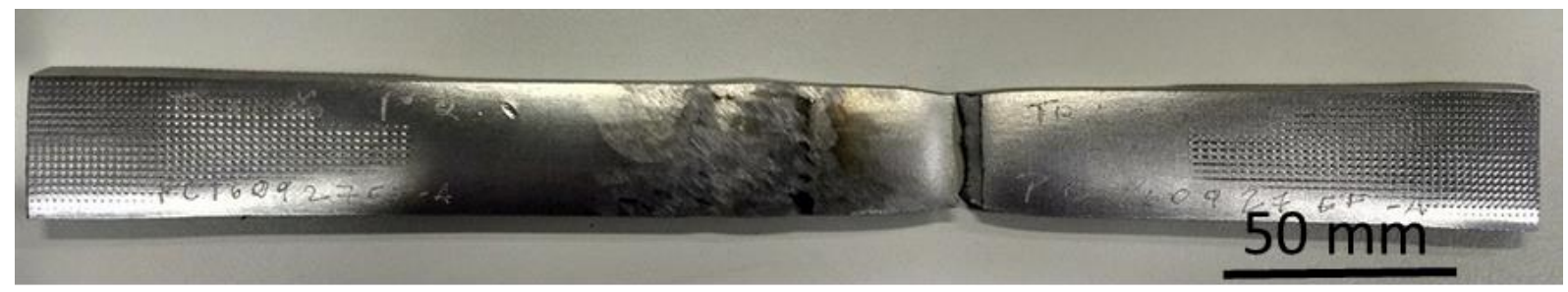

Figure 5: Fractured tensile specimen.

To understand the hardness and failure results, microstructural analysis was taken in the weld cross section.

\section{Microstructure}

Figure 6 shows the SAF 2507 base metal. It displays white austenite islands embedded in a gray matrix of ferrite. Both have elongated shapes with volume fractions of 0.58 and 0.42 , respectively, measured using a ferristoscope Fischer FMP30. 


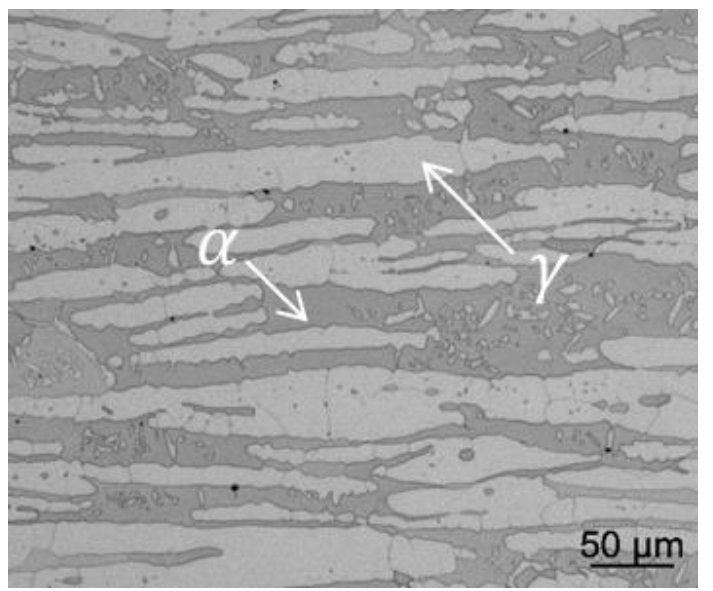

Figure 6: Base metal metallography.

The welded cross section was analyzed, focusing in three main regions: advancing side, retreating side and root, seen in Figure 7. On the welded condition, the thermomechanically affected zone (TMAZ) is noticeable in the advancing side, showing a sharp morphology, being limited to $50 \mu \mathrm{m}$ distance from the stir zone. In addition, the material in the TMAZ region shows severe grain deformation, reorientated perpendicular to the weld traverse direction of the base metal due to the stirring action of the rotating tool. In the retreating side, a smoother transition between stir zone and base metal was noted.

In the stir zone, the morphology of ferrite and austenite islands was much different from that of the base material. The grain size of austenite and ferrite in the stir zone were smaller than those in the base metal. During FSW, the material in the stir zone experiences large shear stresses along the pin tool surface and exposure to high temperatures (13). These conditions combined suggest that dynamic recrystallization occurred both in the austenite and ferrite phases during FSW.

Comparing the two sides of the stir zone, grain size of austenite and ferrite in the AS showed smaller values compared to grains in the retreating side. A previous study investigating material flow of FSW using an in situ marker technique showed that material located on the advancing side of the stir zone is displaced around the entire circumference of the pin tool, leading to a severe deformation, which would tend to break up the austenite islands producing a smaller grain size (14).

In the root, an intense grain refinement was also observed, with some elongated ferrite dispersed in the region. The smaller grain sizes found in that region suggest that material was exposed to lower thermal cycles and/or faster cooling, preventing grain growth in that region.

Thermal simulation was performed to verify the thermal cycles along the joint thickness. 

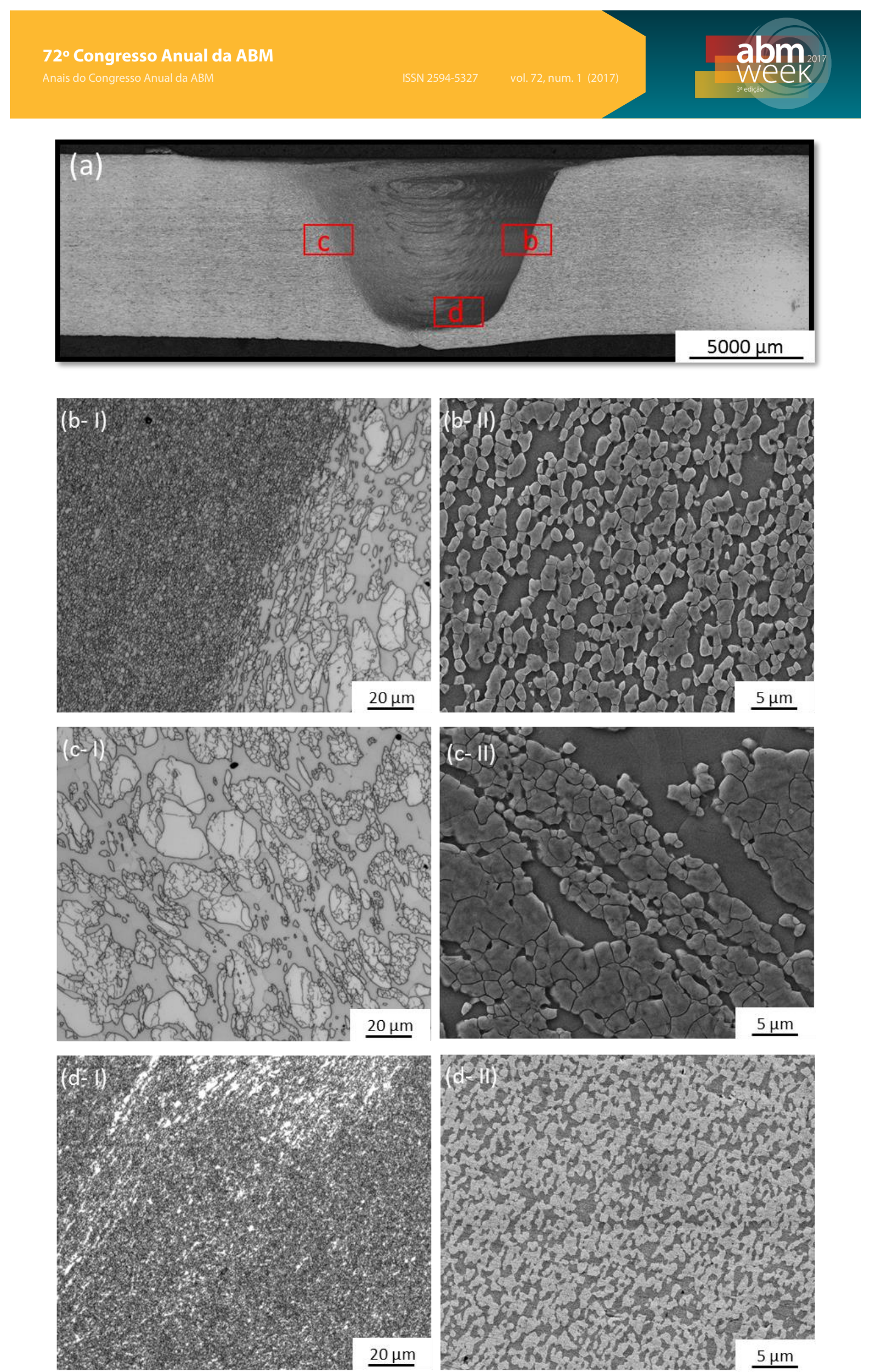

Figure 7: (a) Metallography in welded cross-section of SAF 2507 steel pipe, (b) advancing side, (c) retreating side, (d) root. 


\section{Thermal simulation}

To support the microstructural evolution analysis, temperatures during the process were calculated by numeric simulation. The model was calibrated using the temperature measurements from the thermocouple located in the collar of the friction stir tool. As seen in Figure 2, temperature in the tool reached values around $780-800$ ${ }^{\circ} \mathrm{C}$. Figure 8-(a) shows the simulation results. The model exhibits good agreement with the reference tool thermal cycle curve. In Figure 8-(a), the maximum temperature calculated in the model was $1176{ }^{\circ} \mathrm{C}$.

Santos et al (2014) predicted a global maximum temperature equal to $1183^{\circ} \mathrm{C}$ located near the tool pin and $0.145 \mathrm{~mm}$ below the tool shoulder in a 6 -mm-thick plate. In this way, it can be noticed that regardless of the thickness similar temperatures are achieved near the shoulder, which is the major energy source of the process.

According to Figure 8-(b), simulation results show that volume material close the tool shoulder ( $2 \mathrm{~mm}$ depth) experimented longer periods at high temperatures $\left(>1100{ }^{\circ} \mathrm{C}\right.$ ) than the lower regions of the cross section ( $7 \mathrm{~mm}$ depth). Also, due the proximity to the backing plate, materials in lower regions experience faster cooling rates than outer region materials. Is this way, material located in lower regions suffer deformation but in lower temperatures $\left(\sim 1000{ }^{\circ} \mathrm{C}\right)$ and faster cooling rates $\left(\dot{T}_{12 / 8}=40\right.$ ${ }^{\circ} \mathrm{C} / \mathrm{s}$ ), conferring to ferrite and austenite grains, as seen in microstructural analysis, less energy to undergo grain growth after dynamic recrystallization.

This phenomenon is directly caused by the dimension of the pin and its limitation to provide the same amount of energy along the entire pin length. As the length of the pin increases, the distance between materials deformed and the major heat source of the process (tool shoulder) also increase. This results in different thermal cycles applied to the material along the thickness processed by friction stir welding. Different thermal cycles provide microstructures that exhibit disparate mechanical behavior along the welded joint. 


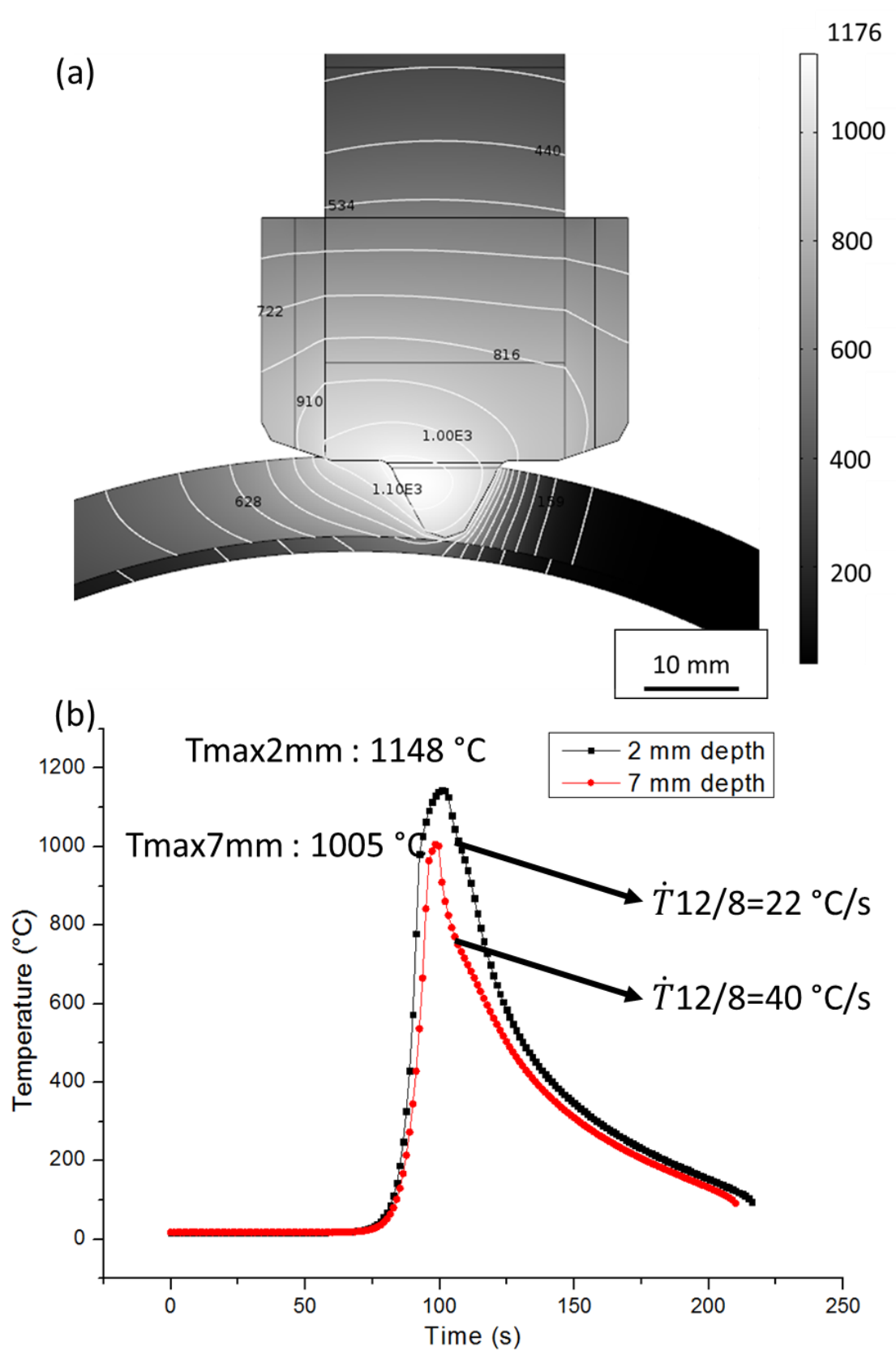

Figure 8: (a) Longitudinal isothermal curves of the friction sitr Welding, (b) Thermal cycles calculated at $2 \mathrm{~mm}$ and $7 \mathrm{~mm}$ from the outer surface.

\section{CONCLUSION}

The present study examined the microstructure and mechanical properties of an 8-mm-thick friction stir welded SAF 2507 super duplex stainless steel pipe. The following conclusions were made:

- Force control mode produced small flash and no superficial defects high-quality welds.

- Hardness tests revealed maximum values of $400 \mathrm{HV}$ in the root region. The overall stir zone reached values around $325 \mathrm{HV}$, slightly higher in the advancing side.

- Tensile tests resulted in failure on lower hardness sites, located in the base metal. 
- In the root, an intense grain refinement was also observed, with some elongated ferrite dispersed in the region. The smaller grain sizes found in that region suggest that material was exposed to lower thermal cycles, preventing grain growth.

- The simulation results show that volume material along the upper regions of the pipe experimented longer periods at high temperatures $\left(>1100{ }^{\circ} \mathrm{C}\right)$ than the bottom region of the cross section. Material located in the bottom region receives less energy, which hinders grain growth after dynamic recrystallization.

- As the length of the pin increases, the temperature gradient between the outer and inner surfaces of the pipe also increases, because the major heat source of the process is the tool shoulder. This results in different thermal cycles applied to the material along the thickness processed by friction stir welding, which provide disparate microstructures and mechanical behavior.

\section{Acknowledgements}

The authors acknowledge Petrobras and FINEP for financial support.

\section{REFERENCES}

$1 \quad$ ASM Specialty Handbook: Stainless Steels. ASM International; 1994.

2 Voronenko Bl. Austenitic-ferritic stainless steels: A state-of-the-art review. Met Sci Heat Treat. 1997 Oct;39(10):428-37.

3 Mishra RS, Mahoney M. Friction stir welding and processing. ASM International. 2007. 2 p.

4 Sato YS, Nelson TW, Sterling CJ, Steel RJ, Pettersson CO. Microstructure and mechanical properties of friction stir welded SAF 2507 super duplex stainless steel. Mater Sci Eng A. 2005;397(1-2):376-84.

5 Saeid T, Abdollah-zadeh A, Assadi H, Malek Ghaini F. Effect of friction stir welding speed on the microstructure and mechanical properties of a duplex stainless steel. Mater Sci Eng A. 2008;496(1-2):262-8.

6 Santos TFA, Idagawa HS, Ramirez AJ. Thermal history in UNS S32205 duplex stainless steel friction stir welds. Sci Technol Weld Join [Internet]. 2014 Feb 6;19(2):150-6. Available from: http://www.tandfonline.com/doi/full/10.1179/1362171813Y.0000000174

7 Perrett JG, Martin J, Threadgill PL, Ahmed MMZ. Recent developments in friction stir welding of thick section aluminium alloys. 6th World Congr Alum Two Thousand [Internet]. 2007;(October):1-7. Available from: http://www.twi-global.com/technicalknowledge/published-papers/recent-developments-in-friction-stir-welding-of-thicksection-aluminium-alloys-march-2007/

8 Esmailzadeh M, Shamanian M, Kermanpur A, Saeid T. Microstructure and mechanical properties of friction stir welded lean duplex stainless steel. Mater Sci Eng A [Internet]. Elsevier; 2013;561:486-91. http://dx.doi.org/10.1016/j.msea.2012.10.068

Available from:

9 Santos TF de A, Torres EA, Ramirez AJ. Soldagem por Atrito com Pino Não Consumível de Aços Inoxidáveis Duplex. Soldag Inspeção [Internet]. 2016 Mar;21(1):59-69. Available from: http://www.scielo.br/scielo.php?script=sci_arttext\&pid=S010492242016000100059\&lng=pt\&nrm=iso\&tlng=en

10 Schmidt $\mathrm{H}$, Hattel J. Modelling heat flow around tool probe in friction stir welding. Sci Technol Weld Join [Internet]. 2005 Apr 4;10(2):176-86. Available from: http://www.maneyonline.com/doi/abs/10.1179/174329305X36070

11 Colegrove $\mathrm{P}$ a., Painter M, Miller T. 3 dimensional flow and thermal modeling of the friction stir welding process. In: Proc 2nd Int Symp on Friction Stir Welding. Gothenburg, Sweden: The Welding Institute; 2000. 
12 Santos TF, Hermenegildo TF, Afonso CRM, Marinho RR, Paes MTP, Ramirez AJ. Fracture toughness of ISO 3183 X80M (API 5L X80) steel friction stir welds. Eng Fract Mech. 2010;77(15):2937-45.

13 Yutaka SS, Hiroyuki H, Ikeda K, Enomoto M, Jogan S, Hashimoto T. Microtexture in the friction-stir weld of an aluminum alloy. Metall Mater Trans A Phys Metall Mater Sci. $2001 ; 32(4): 941-8$.

14 B. London, M. Mahoney, W. Bingel, M. Calabrese, R.H. Bossi DW. Material flow in friction stir welding monitored with AI-Sic and AI-W composite markers. In: Proc Symp on FSW \& Processing II. Warrendale, PA; 2003. 